\title{
APOLITENESS ANALYSIS ON TEACHERS VOICES, A PRAGMATICS STUDY
}

\author{
${ }^{1}$ Syafrianto SM., ${ }^{2}$ Maria Wulandari \\ ${ }^{1}$ STMIK EL RAHMA Yogyakarta, ${ }^{2}$ IAIN Surakarta \\ E-mail: ${ }^{1}$ syafrianto@stmikelrahma.ac.id, ${ }^{2}$ mariawlndr@gmail.com
}

\begin{abstract}
Politeness is a visible feature of communication. A conversation is regarded as a polite conversation and an impolite one occasionally. The context is a meaningful aspect to acknowledge this meaning. It covers age, situation, place, relationship, etc. The mode of communication may also be acknowledged as a context. Along with the globalization era, mode of communication also grows and thrives to be diverse modes such as telephone and social media which enable people to communicate in face-to-face communication. One of the renowned modes is Facebook. On Facebook, as it is known that there are miscellaneous areas of people creating some groups to communicate where one may post or/ and comment on other's wall. What the members do is like what they do in the real conversation. As in real society, they should also consider how to be polite in virtual communication. Thus, this paper is to discuss the politeness principles \& strategies in Facebook conversation. The excerpts of the conversation are obtained from a professional group named Teachers Voices (TV). The group's members were academicians such as lecturers, teachers, graduate students and others who are interested in English language studies.
\end{abstract}

Keywords: politeness, Facebook, conversation

\begin{abstract}
Abstrak
Kesopanan adalah hal yang penting dalam berkomunikasi. Sebuah percakapan ada kalanya dianggap sebagai sebuah percakapan yang sopan di satu sisi dan tidak/ kurang sopan di sisi yang lain. Konteks [social budaya] adalah hal yang penting dipahami untuk memahami makna ini. Seiring dengan era globalisasi, mode komunikasi tumbuh dan berkembang ke dalam mode yang bervariasi pula seperti telepon dan media social yang memudahkan orang-orang dalam berkomunikasi. Salah satu mode yang dikenal luas adalah Facebook. Di Facebook, sebagaimana yang kita ketahui terdiri dari berbagai macam latar belakang pengguna yang membuat beberapa grup untuk berkomunikasi dimana setiap orang/ pengguna bias mengirimkan pesan atau memberikan komentar pada beranda pengguna lain. Apa yang mereka lakukan sesungguhnya sama seperti yang mereka lakukan dalam kehidupan sehari-hari. Sebagaimana di situasi nyata/riil, mereka juga harus mempertimbangkan kesopanan dalam berkomunikasi. Oleh karena itu, artikel ini bertujuan untuk mendiskusikan prinsip dan strategi kesopanan dalam percakapan Facebook. Cuplikan percakapan diperoleh dari sebuah grup professional yaitu Teacher Voices (TV) yang anggotanya terdiri dari akademisi seperti dosen, guru, mahasiswa dan semua pihak yang tertarik pada kajian Bahasa Inggris.
\end{abstract}

Kata kunci: kesopanan, Facebook, percakapan 


\section{INTRODUCTION}

A virtual world is a ubiquitous aspect of modern countries. It is called as animaginary environment by Crystal (2006: 12) which people can enter to engage in text-based fantasy social interaction. Facebook, a model of the virtual world can use to interact with many people around the world. To deal with it, we need not only a good comprehension of English but also a great context and culture understanding. Putting differently, politeness should be assented to communicate with one and another on Facebook.

As you may recall, there are different areas of people on Facebook creating some groups to share and discuss everything of their interests. For this paper's goal, we would like to distinguish between two contexts; the first is that the members of the group have known each other and have some sort of close relationship while the second is that they have not yet known each other. Different context brings a different degree of politeness in the conversation. For example, a professional group like TV which consists of some academicians, educators, lecturers, etc.will be different from those that consist of certain classes of the members.

Studying politeness in one of the notable social media, Facebook is regarded as an influential review to heighten our awareness of being polite among the virtual society.In this paper, we will discuss twofold studies namelypoliteness strategies and politeness principles.Politeness principles deal with the way of explaining how politeness operates in conversational exchanges. Meanwhile, politeness strategies can be seen as the efforts to save the hearer's 'face' inthe conversation.Before discussing the results of the analyses, some related theories will be clarified as follows.

\section{Speech act}

Speech acts are acts performed in uttering expressions (Akmajian et al, 2001: 394).As we talk, we are performing certain acts (Finch, 2000: 180). According toAustin (1962 in Finch, 2000: 180), there are three substantial categories of speech acts i.e. locutionary, illocutionary and perlocutionary act. Locutionary Act, 
as stated by Austin (1962 in Cruse, 2000: 331), is as "the utterance of certain noises..., certain words in a certain construction, and the utterance of them with a certain sense and a certain reference," while Illocutionary Act is an act performed in saying something (Austin, 1962 as cited in Akmajian, 2001: 395). Otherwise stated, it is the type of function the speaker intends to fulfill by saying the utterance (Huang, 2007: 102). For instancein saying "She can do the assignment well", one might perform the act of asserting that she can do the assignment well. Some other illocutionary acts are: promising, reporting, stating, asking, telling, threating, requesting, suggesting, ordering, proposing (Akmajian, 2001: 395). Meanwhile, Perlocutionary Act is an act performed by the addressee as the effect of an utterance by the speaker. For example, in an armed bank robbery, a robber may utter "The gun is loaded" to get the cashier to open the safe (Huang, 2007: 103).

Among those categories, illocutionary act is a challenging one to discuss since it is related to what speakers intend to say. As for talking, the speaker has something to say in their mind as a means to achieve the goal of communication. The addressee should understand the speaker's intention or the function of the utterance the speaker produces.Searle (Huang, 2007:106)proposes some types of speech actreflecting the function of the utterances i.e. representatives, directives, commissions, expressive and declarative.

$\underline{\text { Representativesor assertive }}$ arekinds of speech act that commit the speaker to the truth of the expressed proposition and thus carry a truth value. They express the speaker's belief including the act of asserting, claiming, concluding, reporting, and stating.Directives are those that represent the speaker's attempts to get the addressee to do something, for example, advice, commands, orders, questions, and requests. Commissions are those kinds of speech act that commit the speakers to some future course of action. They express the speaker's intention to do something. It includes offers, pledges, promises, refusals, and threats. Expressives are those 
kinds of speech act that express a psychological attitude or state in the speaker such as joy, sorrow, and the likes/dislikes. Declarative is those kinds of speech act that effect immediate changes in some current state of affairs. In performing this kind of speech act, the speaker brings about changes in the world. The example includes bidding in the bridge, declaring a war, excommunicating, firing from the environment, and nominating a candidate.

The speech act theory proposes a popular principle for a better conversation that may be carried out by the speaker and addressee. That principle is called the cooperative principle. Cooperative principle is a term derived from H.P. Grice.It is a substantial concept in pragmatics relating especially to the study of conversation. Grice's principle assumes that people cooperate in the process of communicationto reduce misunderstanding (Finch, 2000: 160). Speakers should pay attention to some principles for the better conversation i.e. the maxim of quality, the maxim of quantity, the maxim of relation and maxim of manner. In a more recent development, the cooperative principle has been refined in two main ways - politeness principle and relevance theory.In this paper, we will limit the discussion only on the politeness principle. It is as suggested by Leech (1983) is a way of explaining why people feel the need to be indirect in conveying what they mean (Finch, 2000: 161). It will be clarified further under the discussion about politeness theory below.

\section{Politeness Theory}

Politeness, as clarified by Leech, is a type of behavior that allows the participants to engage in social interaction in an atmosphere of relative harmony.Politeness, in line with Poedjosoedarmo (1968: 54), can be specified by some assorted ways such as intonation, circuitous phrasing (e.g. Would you care to have a seat?), choice of personal pronoun (e.g. honorifics), or by the addition of a certain particle (e.g. please).

Leech (1983: 80) explains that the essence of politeness as one principle is 'to minimize the effects of 
impolite utterances (negative politeness) and to maximize the politeness of the polite ones (positive politeness)'. Alongside the cooperative principle, Leech has proposed an independent pragmatic principle which he calls the politeness principle (Cruse, 2000: 361). Leech (1983: 132) divides the politeness principles into six maxims namely tact maxim, generosity maxim, approbation maxim, modesty maxim, agreement maxim, and sympathy maxim.

The first maxim is the tact maxim. Dealing with this maxim, we should not impose on others or challenge their right to do as they wish. This maxim is oriented towards the hearer. It can be seen for instance in the context of impositives (the utterances with the function of getting the hearer to do something like commands, requests, beseechments, etc.). Case in point: when someone wants to make a request, it is more polite to say "I am wondering if you could wash the dishes" rather than say "Wash the dishes!"

The second maxim is the generosity maxim. It is a sister to the tact maxim and is oriented towards costs and benefits to the speaker. They are almost the same however the effects are reversed (Leech, 1962 in Cruse, 2000: 364). In a nutshell, the speaker should minimize the benefit and maximize cost to self, e.g., the utterance "Let me wash the dishes" is considered more polite than "I was wondering if I could wash the dishes."

The third maxim is the approbation maxim. This is a tendency to minimize the dispraise of other(s) and maximize praise of other(s). To put it in another way, the speaker should say nice things about other(s) and conversely should avoid saying unpleasant things about other(s). In his article, we use Leech (2005: 14) to illustrate a model of utterances by a guest who praises the host(ess)'s meal. The utterances are as follows: "They are so delicious! Your cuisine is as good as that of a chef at any big restaurant!"

The fourth maxim is the modesty maxim. Cruse (2000: 365) explains that modesty maxim is the natural partner of the approbation maxim, being oriented towards the 
speaker, with the relevant 'values' reversed. In approbation maxim, the speaker should maximize the praise of the hearer and minimize the dispraise of the hearer. In this maxim, the speaker should maximize the dispraise of self and minimize the praise of the self. For example, when someone gives praise to us by saying "You did brilliantly!", it is considered more polite to reply "Well, thank you, but I couldn't have done this without your help" than to say "Yes, didn't I?".

The fifth maxim is the agreement maxim. This suggests that the speaker maximize agreement with the hearer and minimize disagreement with the hearer. So, instead of saying "I disagree", it is regarded as a more polite manner to say "I agree with the general principle, yet in this case, there are mitigating circumstances" (Cruse, 2000: 366).

The sixth maxim is the sympathy maxim. Sympathy, as stated by Cruse (2000: 366), is a matter of a relation between speaker and hearer, and cannot, therefore, be differentially speaker-or heareroriented. This maxim suggests the speaker maximize sympathy (expression of positive feelings) towards the hearer and to minimize antipathy (expression of negative feelings) towards the hearer. Maxim of sympathy can be specified clearly in the expression of understanding, sympathy, empathy, supportiveness, and the like to another person. For example, giving inquiries about people's health by saying "How's your mother? I hope she's feeling better..."

The six studied maxims deal with the manner of explaining how politeness operates in conversational exchanges. Concerning maintaining a good social relationship between the speaker and the hearer, it needs to consider how to save another person's face when someone is involving in a conversation. The theory which is relevant to this is Brown and Levinson's theory of politeness strategies.Brown and Levinson sum up human politeness behavior in four strategies, which correspond to these examples: bald on record, negative politeness, positive politeness, and off-record-indirect strategy. The explanation about each is as follows. 
The bald on record strategy means the speaker is directly saying the message, without minimizing to obligation or threats to the hearer's 'face'. For example, in the situation of emergency, someone will directly say, "help!". Another example is when making a request, someone says something like "take off your shoes" or "turn the lights on".

The positive politeness strategy is the strategy employed by the speaker by avoiding giving offense to others. The speaker should recognize that everyone wants to be respected. Therefore, rather than offense at others, the speaker tries to be friendly and shows some sort of reciprocity. It includes giving compliments, establishing common ground, using jokes, nicknames, honorifics, tag questions, special discourse markers (e.g. please), and in-group jargon or slang.

The negative politeness strategy is the strategy that also suggests the speaker recognize the hearer's face. But, the speaker is in some way imposing on the hearer. Some obvious examples are in the utterance: "I don't want to bother you but..." or "I was wondering if..."

The last strategy is the offrecord politeness strategy. As the name suggests, this is an indirect strategy. This can be done, for example by giving hints (e.g. "It's a bit cold here) or being vague (e.g. perhaps someone should have been more responsible).

\section{METHOD}

This is a pragmatics study employing a descriptive qualitative approach. The data were obtained from the excerpts of Facebook conversation in a professional educational group TVfrom October 2, 2014, to October 18, 2014. For this paper, the analysis and discussion are based on the Speech Act theory according to Searle's taxonomy, politeness principles by Leech and Politeness strategies by Brown and Levinson. The theories are expected to complement each other so that the discussion will be more informative.

To explain the politeness in Facebook conversation especially on $\mathrm{TV}$, some steps have been followed. First, the script is collected from the 
conversation in the TVgroup from October 2, 2014, to October 18, 2014, from Facebook.com. After that,the data were analyzed based on the theory of speech acts. The theory of speech act is from Austin especially about the illocutionary act and Searle's taxonomy of speech acts. Next, some politeness theories were explored from the bulk of literature. Then, Brown and Levinson's theory and Leech's theory were decided to be used in the analysis. After that,the data analysis was conducted. The process of data analysis also includes arranging, classifying and reducing the data. Lastly, the data were presented in the form of a table and description of the politeness principles and strategies identified on TV.

\section{FINDINGS AND DISCUSSIONS}

This section presents the types of speech acts, politeness principles and politeness strategies that are identified on TV.

From the data, it was found that there are four types of speech acts out of five types proposed by Searle. They are representatives, directives, commissive, and expressive. There are no declarative found from the data. These are the percentages of each.

Table 1. Distribution of Speech Acts Type

\begin{tabular}{ccc}
\hline & Aspects & Occurrence Percentages \\
\cline { 2 - 3 } Type of Speech & Representatives & 45 \\
Acts & Directives & 15 \\
& Commisives & 10 \\
& Expressives & 30 \\
& Declarative & 0 \\
\hline
\end{tabular}

This table specifies that the followed by declarative (30\%), most frequent type of speech acts directives (15\%) and commissive appearing in the excerpt of (10\%). conversation is representatives $(45 \%)$, 
1. The Politeness Principles the terms used in the real Reflected in the Conversation conversation; 'speaker' and 'the among the TV's member

Regarding the politeness addressee' for no specific term of both. Nevertheless, the message that principles, there are some pieces of the participants produce in evidence that the conversations on Facebook's timelines or comments is TV are following the Leech's regarded as 'utterance' although it is a politeness principles.In this case, the terms used to address each participant written text. The politeness principles obtained from the data can be of the conversationare the same with classified as follows.

Table 2 The Distribution of the Politeness Principle

\begin{tabular}{ccc}
\hline & Aspects & Occurrence Percentage \\
\cline { 2 - 3 } Types of & Tact maxim & 25 \\
Politeness & Generosity maxim & 20 \\
Principles & Approbation Maxim & 15 \\
(Leech) & Modesty Maxim & 15 \\
& Agreement Maxim & 30 \\
& Sympathy Maxim & 5 \\
\hline
\end{tabular}

The first principle of Leech's politenesstact maxim. As seen in Table 2, there are $25 \%$ of utterances thatcan consider as tact maxim. The example of the utterance is:

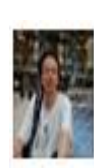

Willy Renandya

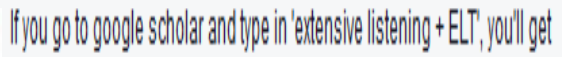
some interesting hiths.

In this part of a comment, it can be clarified that the speaker is in truth giving suggestions. In terms of the Searle's taxonomy, suggesting belongs to directive speech acts. This utterance is regarded as adhering to the tact maxim. It is for the speaker tries to maximize the benefit to the addressee and minimize the cost to the hearer.

Following the context of the conversation, in the part of the comment, the speaker with his pleasure gives the addressee some assistance of how to find the newest materials related to extensive listening for teaching. 
With this suggestion, the addressee is expected to find the materials more easily. In this utterance, tact maxim is adhered by using linguistic feature "if" Instead of saying directly "I suggest you to....", the speaker selects to use "if" at the beginning of his utterance to indicate politeness.

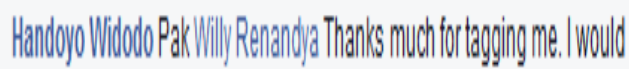

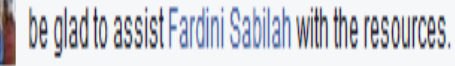

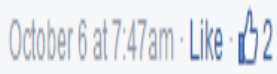

The second principle is generosity maxim. From the analysis, there are $20 \%$ utterances considered as adhering generosity maxim. An example of the utterance containing generosity maxim is:In this part, especially in the second utterance, the speaker is offering help to the addressee. Based on the function of the utterance, this belongs to commisive speech act. It adheres to the generosity maxim for the speaker tries to minimize benefit to self or maximize cost to self.

The third principle is approbation maxim. From the analysis, there were 15 utterances considered as adhering approbation maxim. An example of the utterance is:

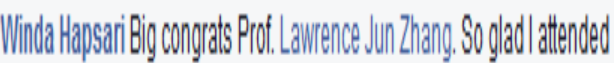

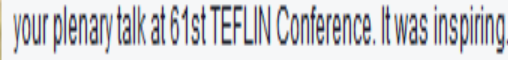

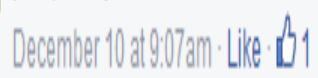

In this excerpt, the speaker congratulates and expresses her feeling of happiness toward the addressee. Therefore, this belongs to the expressive speech act. This utterance adheres to the maxim of approbation because the speaker tries to maximize the praise of the hearer or minimize the dispraise of the hearer.

The fourth principle is modesty maxim. From the analysis, there were $15 \%$ of utterances considered as adhering modesty maxim. The example of the utterance is:

A Donglan Zhang Willy, thanks for the honour extended to me! (1) Now Ifeel the need and responsibility to educate my children to live up to the expectations of this life--Oong membership :--) December 10 at 12:29pm : Like : b1 1

Here, the speaker is responding to someone who congratulates her by thanking. Therefore, this belongs to the expressive speech act. This utterance adheres to the maxim of 
modesty since the speaker tries to minimize praise of self.

In agreement with the context, she is trying to be humble by showing that she still has the responsibility to educate her children although she has been successful in giving a contribution to her husband's success in becoming one of the international scholars.

The fifth principle is agreement maxim. From the analysis, there were $30 \%$ utterances considered as adhering agreement maxim. An example of the utterance is:

Willy Renandya You are absolutely right, Teress. Extennsive listening is the twin sister of extensive reading, though itis only recently that ithas startedth receive research attention.

In this part of the conversation, the speaker is responding to someone's opinion by giving an assertion to a certain topic of discussion. In giving assertion, the speaker agrees with other's opinions. Therefore, this can be classified as a representative speech act. Concerning politeness principles, this utterance adheres to the maxim of agreement. The speaker tries to maximize agreement with the hearer or minimize disagreement with the hearer. According to the context in the conversation, the speaker, in this case, is agreeing Teresa's previous opinion about the existence of many listening tasks which are often dull, long and filled with low frequent words. The speaker expresses the same opinion by strengthening Teresa's opinion using the assertion that extensive listening is the twin sister of extensive reading, which implies that they have almost the same weaknesses.

The last principle of politeness in Leech is sympathy maxim. From the analysis, there were only $5 \%$ of utterances considered as adhering sympathy maxim. An example of the utterance is:

1

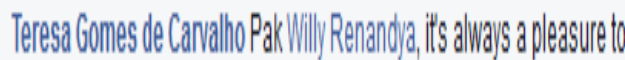

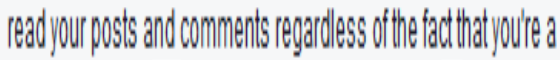
pocositintol.

In this excerpt, the speaker is responding to someone's expressions of guilty. In giving the response, the speaker, in this case, Teresa, tries to encourage Mr. Willy by giving praises for him. This utterance, therefore, can be regarded as an expressive speech act. In terms of the politeness principle, this utterance 
seems to adhere to the maxim of sympathy. It can be explained by the context of this conversation. According to the context, Mr. Willy previously expresses his disappointment with his work because he cannot avoid being a procrastinator. Teresa's comment means that she tries to give sympathy to Mr. Willy by using utterances containing the expressions of supportiveness.

Politeness principles applied in the conversation are various. From the utterances identified in the analysis, the most frequently used maxim is the agreement maxim. When someone makes an opinion in the group's timeline, it is very common that everyone interested in the conversation will give their comments towards that opinion. Most of their comments toward an opinion in the TV's conversation are characterized by agreement maxim. People in the conversation tend to agree to what other people's opinion towards something. If someone disagrees with an opinion or even a piece of information posted on the Facebook group timeline, she/he usually will use an expression of partial agreement. The example of disagreement is as follows.

Winda Hapsari I share similar reasons to you, Lidya. Butif I have to putiti into priorities, first I would check the grand theme and strands of the conference. Then I would check the list of invited speakers. Those are usually the first two factors that attract me to attend a certain conference. Later I surely check the dates and location. And finally I would see the budget.

To be honest, Often times the last factor becomes the most deciding factor whether or not l eventually come to a conference. (i:)

In this excerpt, the speaker tries to agree to some parts of the other's opinion first, then she goes to express her own opinion. The utterance "I share similar reasons to you. But....." indicate the way she tries to be polite in responding to another person's opinion.

\section{The Politeness Strategies}

\section{Reflected in the Conversation among the Members of TV.}

The results of the analysis also show that there are some politeness strategies employed in the conversation. The utterances are classified under each of the politeness strategies. Table 3 shows the classification of politeness strategies found in the excerpt of the conversation. 
Table 3 The distribution of Politeness Strategies

\begin{tabular}{lcc}
\hline Politeness & Aspects & Occurrence Percentage \\
\cline { 2 - 3 } Strategies & Bald on record & 25 \\
(Brown \& & Positive politeness & 40 \\
Levinson) & Negative politeness & 25 \\
\hline
\end{tabular}

The examples are elaborated one by one as follows.The first politeness strategy by Brown and Levinson is bald on record. From the analysis, there are some utterances considered bald on record. The example is:

\section{W. Willy Renandya You should contribute a chapter, Ricky. 1. December 11 at 2:53pm - Like}

The utterance above belongs to a directive speech act. In the directive, the speaker attempts to get the addressee to do something. In this case, Mr. Willy advises someone else named Ricky. From this excerpt, it is obvious that the politeness strategy employed by Mr. Willy is bald on record. Mr. Willy with his utterance above tends to be direct, clear and concise in advising Ricky. This might be able to be explained by using the context. The speaker, in this case, is older than the addressee and is respected by the addressee. Therefore, it does not matter for the speaker for the addressee if the speaker is being direct and concise in the conversation with him.

The second politeness strategy by Brown and Levinson is a positive politeness strategy. From the analysis, there are some utterances considered positive politeness strategy. The examples are:

Lidya Blue Welcome aboard Dr. Barnard! December 11 at 9:58pm - Like - $B 1$

1. Chairil Anwar Korompot Welcome aboard, Prof Masayoshi Kinoshita.

The two utterances above are taken from different conversations. They are similar in terms of the speech act as well as the politeness strategies employed. Referring to Searle's taxonomy, both of them can be classified as an expressive speech act. In this case, the speakers express their psychological attitude or state to other persons. In making utterances, the speakers above employ positive politeness strategies by mentioning 
honorifics of the addressee (e.g. Dr. Barnard, Prof Masayoshi Kinoshita).

The third politeness strategy by Brown and Levinson is a negative politeness strategy. From the analysis, there are some utterances considered negative politeness strategy. An example of those is:

Chan Narith Keuk Could you please send me the file? I cant save itfrom your post. Thanks.

December 11 at 5:43pm - Like

In the utterance above, the speaker intends to get the file that is posted by another person in the Facebook/s timeline. According to Searle's taxonomy, this utterance belongs to a request. In requesting the file, the speaker tries to be polite. It can be inferred that the politeness strategy applied by the speaker here is a negative politeness strategy. It is indicated by the indirectness of the speaker is asking the addressee to send the file. Instead of saying "send me the file", the speaker uses the expression 'could you please.....'.

The last politeness strategy by Brown and Levinson in off-record politeness. From the analysis, there are some utterances considered bald on record. For example: an Handoyo Widodo Additionally, any the submitted manuscripts do not undergo a rigorous peer review process (internal and external screening procedures). October 18, 2013 at 8:44am - Like : B2

According to the context of the conversation, the function of the utterance above is a forgiving suggestion. The discussion is about whether or not to submit a journal in a certain link to the website. In the part of the comment above, it can be inferred that the speaker is suggesting the addressee to avoid submitting the journal to the link that the addressee refers to because the journal submitted through that link will not undergo a rigorous peer review. However, in giving a suggestion, the speaker does not state directly to the addressee. Instead of using the general expression for giving suggestions like 'I suggest you avoid this journal', the speaker tends to use off-record strategy by giving only hints. In other words, the interpretation of this utterance is left to the addressee.

Some combination of politeness strategies might also be used in the Facebookconversation. This usually occurs in a longer utterance. The example is as follows. 
Lidya Blue I dont think so. I think the paper does not cover implicitly how w! should do before choosing the "right" conferences. Some conferences mig not suit our need directly. Since we have limited time allowance to leave ou work and might also have limited budget, we have to carefully decide in advance which conferences are the best for us.

Yesterday at 10:04am - Like - B2

The utterance above shows that the speaker is giving an opinion by asserting about how to select appropriate conferences to be attended. The politeness strategies used by speakers here are two kinds. They are bald on record and negative politeness strategy. By uttering "I don't think so" rather than using a kind of positive politeness strategy like by giving partial agreement first (e.g. I agree, but....), the speaker can be regarded as using bald on record strategy. The possible reason for this is that the speaker wants to say something clearly and to avoid ambiguity. The speaker also uses negative politeness strategy. It is indicated by the use of the plural pronoun 'we' rather than using 'you' in her utterance of giving opinion or assertion.

It has been stated that the TV's members are experts, academicians, educators and those who have the same interest in English Language Studies. They might have a very high awareness of respecting each other. They are likely to have a good understanding that every person wants to have his/her public selfimage appreciated, understood, liked and approved by others. Besides that, some of them are familiar with each other but some others are not. Regardless of the familiarity, most of them are considered polite in their conversation. They use various types of politeness strategy in their conversation. To conclude, the most frequently used strategy is positive politeness and the least is an offrecord strategy. The possible explanation of this will be something related to the context.

The first context, in order to explain the use of positive politeness, is related to the function of this Facebook group. This Facebook group mainly functions as a place for sharing opinions. When someone shares an opinion, other members tend to give comments. While giving the comments, they tend to save the positive face of others by giving more concern to agreeing what others said rather than making a disagreement. Therefore, there are many chances for 
the members to involve in the conversation by employing positive politeness strategies.

The second context, to explain the use of off-record strategy, is related to the mode of conversation. In a Facebook group conversation, people communicate with each other through written expressions. The limitation of this mode of conversation is that it sometimes cannot depict the real expression of the speakers or utterers. This is different from the act of communication in the real world. The off-record strategy might often be found more frequently in the real world situation than that of the virtual world like Facebook. The advantage of the real-world conversation is that when the speaker conducts an offrecord strategy, it can be interpreted more easily by the addressee because some supporting features such as gestures, facial expressions, and the movement of the speaker while saying the utterance. Conversely, in Facebook conversations, the addressee cannot observe directly those features. Therefore, they rarely use the off-record strategy. This might be because theywant to avoid making misunderstandings in their conversation.

\section{CONCLUSION}

Politeness is a crucial thing in social interaction. It isa kind of toolto maintain social relations among people in daily communication. The virtual world brings a new mode of communication. It enables them to interact and communicate as if they are in the real world although there are some features of communication that might be different from those that are available in real-world communication.

People can access the virtual world in various ways. One of them is by involving themselves in a Facebook group. It is a place that enables people to communicate with each other by sharing posts, giving opinions, suggestions, asking questions, giving pieces of information, and the like. Communication in the Facebook group is actually also bounded to the concept of politeness. Being polite in the conversation will maintain a 
better relationship among the members.

From the data analysis, it can be inferred that there are various speech acts performed by the members including representative, directive, commisive, and expressive. In terms of the usage, the largest speech act identified in the analysis are representative speech act and the smallest one is commisive. In delivering their messages, the group members also applied some principles of politeness by Leech. It was observed that agreement maxim is the most frequently used maxim and the sympathy maxim is the least frequently used in the identified conversation of the TV.

In addition to the politeness principle, politeness strategies were also used by the members of TV. Positive politeness strategy obtained the highest percentage and the offrecord strategy obtained the lowest percentage in the identified conversation among TV group members.

To conclude, from the analyses, it can be inferred that all of the members of the TV have attempted to create good understanding and respect among each other in the conversation. The use of various politeness principles and strategies create a positive environment in this Facebook group. A positive environment can bring advantages to everyone's life.

\section{REFERENCES}

Akmajian, A. et al. 2001. Linguistics: An Introduction to Language and Communication. London: Massachusetts Institute of Technology.

Cruse, A. 2000. Meaning in Language: An Introduction to Semantics and Pragmatics. New York: Oxford University Press.

Crystal, D. 2006. Language and the Internet (2nd edition). Cambridge: Cambridge University Press.

Finch, G. 2005. Key Concepts in Language and Linguistics (2nd edition). Hampshire: Palgrave.

Huang, Y. 2007. Pragmatics. New York: Oxford University Press.

Leech, G. 1983. Principles of Pragmatics. $\quad$ Singapore: Longman Singapore Publishers Ltd. 
Leech, G. 2005. Politeness: Is there an East-West Divide?. Journal of Foreign Languages, 6: 130 .

Poedjosoedarmo, S. 1968. Javanese Speech Level. Indonesia, 6: 54-81. 